\title{
Draft genome sequence of Clostridium jeddahense EE-R19 isolated from an anaerobic digester
}

\author{
Elvira E. Ziganshina ${ }^{1}$, Waleed S. Mohammed ${ }^{2}$ and Ayrat M. Ziganshin ${ }^{1 *}$ (D)
}

\begin{abstract}
Objectives: Clostridium species of the order Clostridiales are mostly strictly anaerobic rod-shaped bacteria. They can be detected in a variety of environments, including the intestines of humans and animals, soil, water, and biogas reactors. Species of the genus Clostridium are widely used in various biotechnological processes, but several of them have been identified as significant human pathogens. Therefore, investigation at the genome level is necessary to provide valuable information about the ecology, genetics, and phylogenetic diversity of various Clostridium species.

Data description: In the present study, we report the whole genome sequence of Clostridium jeddahense strain EE-R19, which was isolated from a mesophilic anaerobic digester. The draft genome of $C$. jeddahense EE-R19 consisted of 59 contigs ( $>500$ bp), which amounted to 3,562,974 with an overall $\mathrm{G}+\mathrm{C}$ content of $51.79 \%$. The whole genome shotgun project of $C$. jeddahense EE-R19 has been deposited at DDBJ/ENA/GenBank under the accession number JAAVNF000000000.
\end{abstract}

Keywords: Draft genome, Firmicutes, Clostridium jeddahense, Anaerobic digester

\section{Objective}

Members of the order Clostridiales can be found in a variety of environments, including the intestines of humans and animals, soil, water, marine environments, and biogas reactors [1-4]. The clostridia are basically strict anaerobes with gram-positive staining and the ability to sporulate. Their metabolism varies greatly because they can metabolize various compounds, including carbohydrates, proteins, alcohols, amino acids, and purines. Organic acids and alcohols can be obtained during the metabolism of carbohydrates or proteins. However, some of them have been identified as human pathogens [1]. The genome data will expand understanding of the

\footnotetext{
*Correspondence: ayrat.ziganshin@kpfu.ru

${ }^{1}$ Department of Microbiology, Institute of Fundamental Medicine and Biology, Kazan (Volga Region) Federal University, Kremlyovskaya Str. 18, Kazan 420008, Russia

Full list of author information is available at the end of the article
}

genus Clostridium and provide valuable information about ecology and genetics of the species Clostridium jeddahense.

\section{Data description}

Clostridium jeddahense strain EE-R19 was originally isolated from anaerobically digested distillers grains and cow manure at mesophilic temperatures on nutrient agar plates in a BACTRON anaerobic chamber (Shel Lab) in Kazan, Republic of Tatarstan, Russia. The strain C. jeddahense EE-R19 was then cultivated on nutrient agar plates at $+38{ }^{\circ} \mathrm{C}$ for $72 \mathrm{~h}$ in a BACTRON anaerobic chamber. Biomass from a culture of $C$. jeddahense EE-R19 was harvested, washed twice with sterile K-Na-phosphate buffer ( $\mathrm{pH}$ 7.0), and genomic DNA was extracted by using FastDNA spin kit (MP Biomedicals) according to the manufacture's protocol. The identity of the strain EE-R19 was confirmed based on morphological, biochemical, and growth characteristics, and finally by sequencing

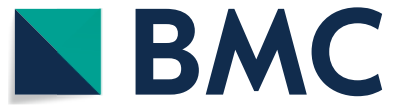

(c) The Author(s) 2020. This article is licensed under a Creative Commons Attribution 4.0 International License, which permits use, sharing, adaptation, distribution and reproduction in any medium or format, as long as you give appropriate credit to the original author(s) and the source, provide a link to the Creative Commons licence, and indicate if changes were made. The images or other third party material in this article are included in the article's Creative Commons licence, unless indicated otherwise in a credit line to the material. If material is not included in the article's Creative Commons licence and your intended use is not permitted by statutory regulation or exceeds the permitted use, you will need to obtain permission directly from the copyright holder. To view a copy of this licence, visit http://creativeco mmons.org/licenses/by/4.0/. The Creative Commons Public Domain Dedication waiver (http://creativecommons.org/publicdomain/ zero/1.0/) applies to the data made available in this article, unless otherwise stated in a credit line to the data. 
Table 1 Overview of data files/data sets

\begin{tabular}{llll}
\hline Label & Name of data file/data set & $\begin{array}{l}\text { File types (file } \\
\text { extension) }\end{array}$ & Data repository and identifier (DOI or accession number) \\
\hline Data set 1 & $\begin{array}{l}\text { C.jeddahense EE-R19, whole } \\
\text { genome shotgun sequencing } \\
\text { project }\end{array}$ & FASTA & Genbank (https://wWw.ncbi.nlm.nih.gov/nuccore/JAAVNF000000000.1) \\
C.jeddahense EE-R19, 16S riboso- \\
mata set 2 & FASTA RA gene, partial sequence & & Genbank (https://identifiers.org/ncbi/insdc:MT253587.1) \\
\hline
\end{tabular}

its 16S rRNA gene (Table 1) (16S rRNA gene sequence, 1385 bp, BLAST identity of $99.33 \%$ to Clostridium jeddahense strain JCD (NR_144697.1)). In addition, the average Nucleotide Identity (ANI) values were estimated using the JSpeciesWS online service for the comparison of the whole genome sequences [5], which confirmed that the strain EE-R19 belongs to the $C$. jeddahense species.

DNA libraries were created as previously reported [6, 7] and according to the Illumina protocol. The genome was then sequenced using an Illumina MiSeq system on a paired-end library with MiSeq Reagent Kit v3 (600cycle). Quality assessment of the FASTQ sequence files was based on the FastQC software (version 0.11.8) [8]. Velvet assembler (version 1.2.10) was used to assemble reads into contigs [9]. Mauve program (version 2.4.0) was used as a contig ordering tool [10]. The bacterial genome annotation was achieved by uploading the genome assembly of the $C$. jeddahense strain EE-R19 to Rapid Annotation using Subsystem Technology (RAST) server [11]. The number of rRNA and tRNA genes was further recognized by using Barrnap (version 0.9) [12] and Aragorn (version 1.2) [13], respectively.

After filtering and quality assessment, reads were then assembled into 59 contigs ( $>500 \mathrm{bp}$ ), finally creating a genome with a total size of 3,562,974, having an average $\mathrm{G}+\mathrm{C}$ content of $51.79 \%$. The RAST server predicted 3972 protein-coding genes. Most of the annotated genes determined the synthesis of amino acids and derivatives (258), carbohydrates metabolism (253), protein metabolism (164), synthesis of cofactors, vitamins, prosthetic groups and pigments (122), and fatty acids, lipids and isoprenoids metabolism (32). Barrnap and Aragorn predicted 5 rRNA and 47 tRNA genes, respectively. The strain $C$. jeddahense strain EE-R19 has several genes involved in the biodegradation of carbohydrates and proteins, mixed acid and lactate fermentation, butanol biosynthesis, as well as in the metabolism of acetoin and butanediol. Moreover, several genes have been identified that are responsible for resistance to toxic compounds, including copper, cobalt, zinc, and cadmium. The genome data presented here should contribute to further research on this organism.

\section{Limitations}

The exact genome length, synteny, number of rRNA genes, and repetitive elements cannot be certainly reported since the data obtained is based on the draft level genome sequence.

\section{Acknowledgements}

Not applicable.

\section{Authors' contributions}

EEZ and WSM conducted experiments, fulfilled genome analysis and interpretation of the data. AMZ designed the study and prepared the manuscript. All authors read and approved the final manuscript.

\section{Funding}

The reported study was funded by the Russian Foundation for Basic Research [Grant No. 18-29-25058]. RFBR did not take part in the design or realization of the study.

\section{Availability of data materials}

The data described in this Data note can be freely and openly accessed at DDBJ/ENA/GenBank. Accession Numbers-https://www.ncbi.nlm.nih.gov/ nuccore/JAAVNF000000000.1 (whole genome project) [14] and https://ident ifiers.org/ncbi/insdc:MT253587.1 (16S rRNA gene sequence) [15].

Ethics approval and consent to participate

Not applicable.

Consent for publication

Not applicable.

Competing interests

The authors have declared that no competing interest exists.

\section{Author details}

${ }^{1}$ Department of Microbiology, Institute of Fundamental Medicine and Biology, Kazan (Volga Region) Federal University, Kremlyovskaya Str. 18, Kazan 420008, Russia. ${ }^{2}$ Department of Biotechnology, Faculty of Agriculture, Al-Azhar University, Cairo 11651, Egypt.

Received: 29 April 2020 Accepted: 21 August 2020

Published online: 03 September 2020

\section{References}

1. Wells CL, Wilkins TD. Clostridia: spore forming anaerobic bacilli. In: Baron S, editor. Medical Microbiology. 4th ed. Galveston: University of Texas Medical Branch; 1996.

2. Lagier JC, Bibi F, Ramasamy D, Azhar El, Robert C, Yasir M, et al. Non contiguous-finished genome sequence and description of Clostridium jeddahense sp. nov. Stand Genomic Sci. 2014;9:1003-19.

3. Ziganshina EE, Belostotskiy DE, Shushlyaev RV, Miluykov VA, Vankov PY, Ziganshin AM. Microbial community diversity in anaerobic reactors 
digesting turkey, chicken, and swine wastes. J Microbiol Biotechnol. 2014;24:1464-72

4. Ziganshin AM, Wintsche B, Seifert J, Carstensen M, Born J, Kleinsteuber S. Spatial separation of metabolic stages in a tube anaerobic baffled reactor: reactor performance and microbial community dynamics. Appl Microbiol Biotechnol. 2019;103:3915-29.

5. Richter M, Rossello-Mora R, Glockner FO, Peplies J. JSpeciesWS: a web server for prokaryotic species circumscription based on pairwise genome comparison. Bioinformatics. 2016;32:929-31.

6. Ziganshina EE, Mohammed WS, Doijad SP, Shagimardanova El, Gogoleva $\mathrm{NE}$, Ziganshin AM. Draft genome sequence of Brevibacterium epidermidis EZ-K02 isolated from nitrocellulose-contaminated wastewater environments. Data Brief. 2018;17:119-23.

7. Mohammed WS, Ziganshina EE, Shagimardanova El, Gogoleva NE, Ziganshin AM. Draft genome sequence of Paenibacillus sp. EZ-K15 isolated from wastewater systems. BMC Res Notes. 2017;10:734.

8. Babraham Bioinformatics. FastQC: a quality control tool for high throughput sequence data. Cambridge: Babraham Institute; 2011.

9. Zerbino DR. Using the Velvet de novo assembler for short-read sequencing technologies. Curr Protoc Bioinform. 2010;11(11):5.

10. Rissman Al, Mau B, Biehl BS, Darling AE, Glasner JD, Perna NT. Reordering contigs of draft genomes using the Mauve aligner. Bioinformatics. 2009;25:2071-3.
11. Aziz RK, Bartels D, Best AA, DeJongh M, Disz T, Edwards RA, et al. The RAST server: rapid annotations using subsystems technology. BMC Genomics. 2008;9:75.

12. Barrnap version 0.9. https://github.com/tseemann/barrnap.

13. Laslett $D$, Canback B. ARAGORN, a program to detect tRNA genes and tmRNA genes in nucleotide sequences. Nucleic Acids Res. 2004;32:11-6.

14. Ziganshina EE, Mohammed WS, Ziganshin AM. Clostridium jeddahense EE-R19, whole genome shotgun sequencing project. Genbank JAAVNF000000000. 2020. https://www.ncbi.nlm.nih.gov/nuccore/JAAVN F000000000.1>

15. Ziganshina EE, Mohammed WS, Ziganshin AM. Clostridium jeddahense EE-R19, 16 S ribosomal RNA gene, partial sequence. Genbank MH651712. 2020. https://identifiers.org/ncbi/insdc:MT253587.1.

\section{Publisher's Note}

Springer Nature remains neutral with regard to jurisdictional claims in published maps and institutional affiliations.
Ready to submit your research? Choose BMC and benefit from:

- fast, convenient online submission

- thorough peer review by experienced researchers in your field

- rapid publication on acceptance

- support for research data, including large and complex data types

- gold Open Access which fosters wider collaboration and increased citations

- maximum visibility for your research: over 100M website views per year

At BMC, research is always in progress.

Learn more biomedcentral.com/submissions 